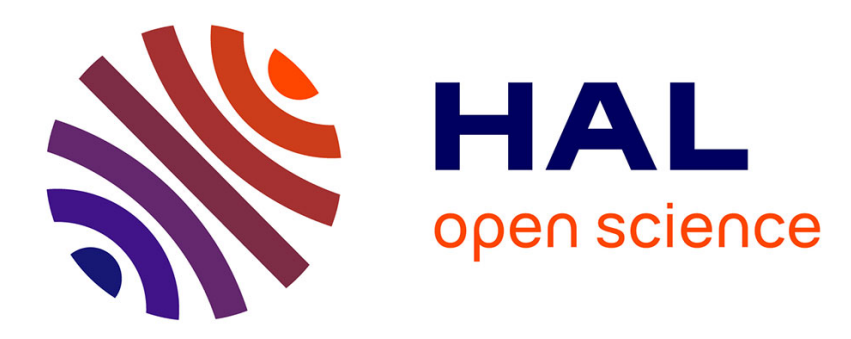

\title{
ULTRASONIC ATTENUATION IN GAMMA IRRADIATED VITREOUS SILICA
}

\author{
G. Londoño, R. Nava
}

\section{To cite this version:}

G. Londoño, R. Nava. ULTRASONIC ATTENUATION IN GAMMA IRRADIATED VITREOUS SILICA. Journal de Physique Colloques, 1985, 46 (C10), pp.C10-453-C10-455. 10.1051/jphyscol:198510100 . jpa-00225300

\section{HAL Id: jpa-00225300 https://hal.science/jpa-00225300}

Submitted on 1 Jan 1985

HAL is a multi-disciplinary open access archive for the deposit and dissemination of scientific research documents, whether they are published or not. The documents may come from teaching and research institutions in France or abroad, or from public or private research centers.
L'archive ouverte pluridisciplinaire HAL, est destinée au dépôt et à la diffusion de documents scientifiques de niveau recherche, publiés ou non, émanant des établissements d'enseignement et de recherche français ou étrangers, des laboratoires publics ou privés. 
JOURNAL DE PHYSIQUE

Colloque C10, supplément au $\mathrm{n}^{\circ} 12$, Tome 46, décembre 1985 page Cl0-453

ULTRASONIC ATTENUATION IN GAMMA IRRADIATED VITREOUS SILICA

G. LONDOÑO and R. NAVA

Centro de Física. Instituto Venezolano de Investigaciones

Científicas (IVIC), Apartado 1827, Caracas 1010A, Venezuela

Abstract - Longitudinal ultrasonic attenuation measurements in four types of gamma irradiated vitreous silicas have been carried out for frequencies between 30 and $90 \mathrm{MHz}$ over the temperature range from 1 to $300 \mathrm{~K}$. The magnitude and temperature dependence of the low- and high-temperature ultrasonic relaxations characteristic of glasses were found to be independent of the degree of room temperature gamma irradiation to a dose of 10 MRads. The results indicate that the low activation energy dielectric center created by gamma rays in impure silicas is not acoustically active.

\section{I - INTRODUCTION}

On the basis of production processes fused silica is commercially available in four types. Table I lists some of the reasonably well defined characteristics of the different silica glasses $/ 1,2 /$ which make them useful for comparative studies of their properties. Dielectric measurements in fused silicas /2,3/ have established that the magnitude of the low frequency dielectric losses is sensitive to metallic and polar impurities. Type I and to some extent Type II fused silicas show a $240 \mathrm{~K}$ relaxation which is unnoticeable in Types III and IV, whereas high-OH content silicas show a He-temperature loss whose magnitude increases with OH-content. In addition, all types of fused silica show a $40 \mathrm{~K}$ relaxation which appears to be only weakly influenced by the overall impurity content. Upon irradiation with ganma rays no dielectric loss changes are observed in either Type III or Type IV silicas. However, for Infrasil samples the $240 \mathrm{~K}$ relaxation is destroyed by gamma irradiation and a lower activation energy relaxation is created in the region around the $40 \mathrm{~K}$ relaxation $/ 2 \%$. This radiation response suggested a specific model for the origin of the high temperature and the gamma-ray induced relaxations in Types I and II fused silicas $/ 2 \%$. On the other hand, it is known that the same thermally activated relaxation process is responsible for the acoustic and dielectric losses in silica glasses around 40K. Thus, it can be reasonably expected that ultrasonic atteruation measurements in the four types of fused silica may provide meaningful 
results to compare with their dielectric behavior under gamma irradiation. TABLE I. - Characteristics of commercially available fused silicas (a)

$\begin{array}{llll}\text { Type I } & \text { Type II } & \text { Type III } & \text { Type IV }\end{array}$

\begin{tabular}{|c|c|c|c|c|}
\hline Production process & Electric Fusion & Flame Fusion & Flame hydrol- & P1asma oxida- \\
\hline Starting material & $\begin{array}{l}\text { Natural or re- } \\
\text { fined quartz. }\end{array}$ & $\begin{array}{l}\text { Selected nat- } \\
\text { ural or re- } \\
\text { fined rock } \\
\text { quartz }\end{array}$ & $\begin{array}{l}\mathrm{SiCl}_{4} \text {, etc. } \\
\text { vapor }\end{array}$ & $\begin{array}{l}\text { tion } \\
\text { SiCl }_{4}, \text { etc., } \\
\text { vapor }\end{array}$ \\
\hline Purity & $\begin{array}{l}\approx \text { Rock quartz } \\
50-100 \mathrm{ppm} \\
\text { impurities }\end{array}$ & $>$ Rock quartz & $\begin{array}{l}\text { Extremely } \\
\text { high } \\
50 \text { ppm C1 }\end{array}$ & $\begin{array}{l}\text { Extremely } \\
\text { high } \\
200 \text { ppn } \mathrm{Cl} 1\end{array}$ \\
\hline $\begin{array}{c}\text { Water content } \\
\text { (wt.o) }\end{array}$ & 0.001 & $0.015-0.04$ & $0.08-0.14$ & 0.001 \\
\hline $\begin{array}{l}\text { Samples used in } \\
\text { this work }\end{array}$ & Infrasil & $\begin{array}{l}\text { Uttrasil } \\
\text { Homosil }\end{array}$ & Suprasil & Suprasil W \\
\hline
\end{tabular}

(a) After Ref. $/ 2 /$.

\section{II - EXPERIMENTS AND DISCUSSION}

The attenuation of longitudinal ultrasonic waves of the as-received samples /4/ was measured from 1 to $300 \mathrm{~K}$ by conventional pulse-echo techniques in the frequency range from 30 to $90 \mathrm{MHz}$. $\mathrm{PVF}_{2}$ transducers bonded with No-Naq grease were used in all experiments. The samples were surrounded by either liquid or gaseous Helium and their termerature determined by calibrated Ge-thermometers. Since the same transducer bonding agent was used throughout a wide temperature range phase effects limit the accuracy of the attenuation magnitude to about $15 \%$.

The acoustic properties of Suprasil before and after gamma irradiation have been reported in the literature $/ 5 /$ thus, the present experiments are limited to samples of Infrasil, Ultrasil, Homosil and Suprasil W. The attenuation of the irradiated samples was measured after each irradiation at room temperature in a co-60 source to a maximun dose of 10 MRads. The observed (optical) radiation hardness of the four types of silica was found to increase with purity as previously reported $/ 6 /$. We observed however, that our samples of Type II silica did not colored homogeneously: a circular sector in the periphery of the rods of Ultrasil and all but a globular zone tangent to the periphery of the Homosil rods remained almost colorless up to the maximm ganma dose.

The ultrasonic attenuation of the as-received samples as a function of temperature for $60 \mathrm{MHz}$ is shown in Fig. 1 after subtracting the attenuation at $1.3 \mathrm{~K}$. Similar curves were obtained at 30 and $90 \mathrm{MHz}$ except that their amplitudes scale roughly linearly with frequency. As has been observed for other transport properties of amorphous silica and in contrast to the low frequency dielectric losses, the ultrasonic attenuation curves have the same shape and nearly the same magnitude for the different types of fused silica studied in this work.

It was found that room temperature ganma irradiation of the samples to a dose of 10 MRads did not produce any discernible change in the ultrasonic attenuation or its temperature dependence. (Fig. 2). This is a known fact for high purity silicas (Types III and IV) but it is somewhat surprising for the less pure ones (Types I and II) in view of the reported radiation induced excess dielectric loss which is 
quite noticeable at temperatures as low as $20 \mathrm{~K}$. Since our measurements included one Type I and two Type II silicas it may be concluded that the new gamma-ray induced dielectric center in silica with metallic impurities does not couple to longitudinal sound waves.

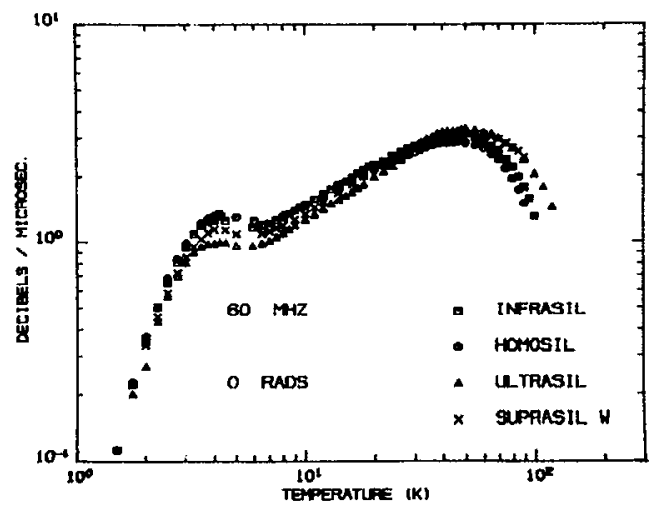

Fig. 1 - Attenuation of longitudinal waves in as-received samples of fused silica.

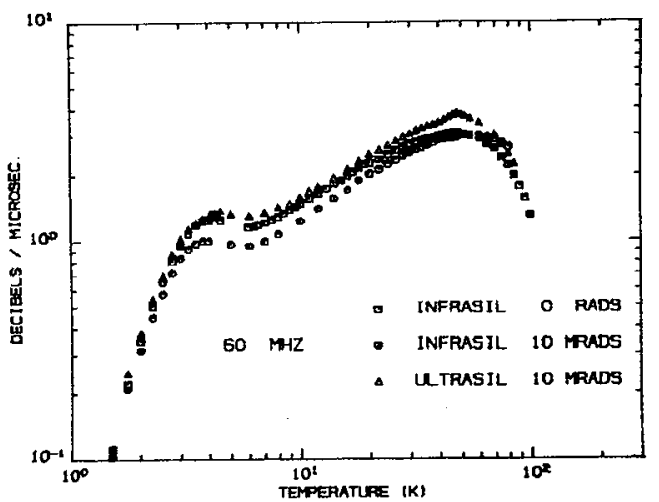

Fig. 2 - Attenuation of longitudinal waves in gamma irradiated fused silica.

\section{REFERENCES}

/1/ Brückner, R., J. Non-Crystalline Solids 5 (1970) 123.

/2/ Fontanella, J., Johnston, R.L., Sigal, Jr., G.H., and Andeen, C., J. Non-Crystalline Solids 31 (1979) 401.

/3/ Mahle, S.H., and McCammon, R.D., Phys. Chem. Glasses 10 (1969) 222.

/4/ Heraeus -Amersil, Inc., materials cut and polished by Valpey-Fisher Corp., USA.

/5/ Strakna, R.E., Clark, A.E., Bradley, D.L., and Slic, W.M., J. Appl. Phys. 34 (1963) 1439.

/6/ Brückner, R., J. Non-Crystalline Solids $\underline{5}$ (1971) 177. 